\title{
Analysis of Foreign Exchange Transactions (Al-Sharf) Variety in Review of Islamic Law in Indonesia
}

\author{
$1^{\text {st }} \mathrm{Jm}$. Muslimin ${ }^{1}, 2^{\text {nd }}$ Mujibu Da'wat ${ }^{2}, 3^{\text {rd }} M$. Hilal Afdhal ${ }^{3}, 4^{\text {th }}$ Rachmanto Dwi Nugroho ${ }^{4}$, \\ $5^{\text {th }}$ Syahrul Romadon Rambe ${ }^{5}, 6^{\text {th }}$ Siti Ummi Masruroh ${ }^{6}, 7^{\text {th }}$ Usep Abdul Matin ${ }^{7}$ \\ \{jm.muslimin@uinjkt.ac.id ${ }^{1}$, mujibudawat_21@mhs.uinjkt.ac.id ${ }^{2}$, \\ mhilalafdhal21@mhs.uinjkt.ac.id ${ }^{3}$, rachmantodwinugroho21@mhs.uinjkt.ac.id ${ }^{4}$, \\ syahrulromadonrambe21@mhs.uinjkt.ac.id ${ }^{5}$,ummi.masruroh@uinjkt.ac.id ${ }^{6}$, \\ usep.abdulmatin@uinjkt.ac.id ${ }^{7}$ \} \\ UIN Syarif Hidayatullah Jakarta ${ }^{1,2,3,4,5,6,7}$
}

\begin{abstract}
Analysis of Variety of Foreign Exchange Transactions (Al-Sharf) in the Review of Islamic Law. The purpose of this study is to find out the views of Islamic law in Indonesia regarding foreign exchange transactions or Al-Sharf which is one of the transaction tools that affects the fulfillment of basic human needs globally today. Buying and selling currency is allowed as long as it is paid in cash and the exchange rate of a country's currency will be exchanged for the exchange rate of the currency desired by the buyer. This factor will be examined by the author using the approach of norms and sources of Islamic law, especially those that apply in Indonesia. This research is literature research conducted by reviewing various documents, both books, and writings that discuss foreign exchange buying and selling which are studied and analyzed based on the view of Islamic law.
\end{abstract}

Keywords: Foreign Exchange, Al-Sharf, Islamic Law

\section{Introduction}

The current foreign exchange rate is increasing almost every day and tends to be unstable due to several conditions. One of them is due to differences in inflation in each country. In Indonesia, the annual inflation rate is around 4 percent, while in the United States it is around 2 percent so that the current exchange rate of the rupiah against the US dollar continues to appreciate. Currently, the rupiah exchange rate has penetrated at Rp. 14,600, this number will continue to increase if the inflation rate reaches 5 percent [1]. The government must participate in maintaining prices in the market to minimize the increase in the exchange rate. If the government does not control prices, the exchange rate can increase.

The instability of domestic political conditions can cause the exchange rate to plummet because many foreign funds have fled abroad and foreign investors are reluctant to invest in Indonesia [2]. Political crises, health problems due to a protracted pandemic without special supervision from the government can have an impact on an economic crisis where this economic crisis can harm all parties, both from within the country and from abroad. The government's ability to control all domestic problems can have a good impact because it can convince foreign investors to invest their capital back into the country. Bank Indonesia is expected to be able to provide convenience for banks when they want to carry out export-import financing activities 
because so far exporters and importers have experienced difficulties due to the impact of covid$19[3]$.

\section{Literature Review}

From the results of existing research, many scientific works discuss foreign exchange (forex) transactions, including the following:

Setiawan Budi Utomo, Agus Fajri Zam and Iwan Kurniawan, Journal of Media Research and Management FE Trisakti Jakarta in 2008, entitled "Analysis of the Conformity of Conventional Hedging Instruments to Sharia Principles". In this study, we offer mudharabah and musyarakah contracts as a form of hedging development so that it can be carried out as a protective value for Islamic values that can be accepted because the hedging concept that is currently developing and is not following sharia [4].

Muhammad Sulhan, in a journal entitled "Foreign Exchange Transactions (Al-Sharf) in an Islamic Perspective" in 2008. The results of this study conclude that on a sharia principle based on Islamic legal norms that the practice of buying and selling foreign exchange is allowed based on consensual and voluntary between the two parties without any element of coercion and is carried out in cash and there is no addition between an item of the same kind (gold with gold or silver with silver). If there are different types, such as gold and silver or in currencies such as rupiah for dollars or vice versa, it can be exchanged according to the market rate (market price) with a note that it must be in cash (spot) [5].

Nanik Indrawati, in a thesis entitled "Application of Risk Management in Foreign Exchange (FOREX) Investment (Study At PT. Victory International Futures Malang Branch Office)" in 2009. This study aims to describe the mechanism of forex transactions and risk management applications applied at PT. . Victory International Futures Malang branch office in Forex transactions. Existing risk management is provided to investors, namely before and during transactions [6].

Rita Sahara, in the thesis entitled "Foreign Exchange Transactions in the Islamic Economic Perspective" 2010. The purpose of this study is to analyze the basis of Foreign Exchange transactions in the Islamic Economic Perspective and the Meeting Point for Differences in Foreign Exchange Transaction Activities [7].

\section{Methodology}

Research is a scientific activity related to analysis and construction which is carried out methodologically, systematically, and consistently. Methodological means according to a certain method or method, systematic is based on a system, while consistent means that there are no contradictory things within a certain framework [8].

In the application of Islamic law in Indonesia, especially regarding sharia economic law, the doctrine that is often used as the basis for drafting laws and regulations and the basis for judges in deciding cases in the sharia economy is the of the National Sharia Council in Indonesian Ulema Council (DSN-MUI). As a source of law which is categorized as a doctrine (opinion of experts/legal experts), the position of the MUI DSN Fatwa is only limited to aspirational law which can be transformed into positive law if it has been promulgated in-laws and regulations or decided in a court decision that has permanent legal force, and eventually becomes jurisprudence. In this case, there is a DSN MUI Fatwa that regulates foreign exchange 
transactions, namely Fatwa DSN 28/DSN-MUI/III/2002 about the Sale and Purchase of Currency (Al-Sharf).

\subsection{Theoretical Basis}

\subsubsection{Overview of Foreign Exchange}

The foreign exchange rate is the comparison of the foreign currency value expressed with the domestic currency value. Foreign exchange (Forex) is the currency issued as legal tender in another country. A foreign currency will have value if it can be exchanged for another currency without limitation. Then the place where supply and demand for foreign exchange meet are called the Foreign Exchange Market [9]. Forms of Foreign Exchange Transactions Based on the type of transaction, foreign exchange transactions can be grouped into four groups, namely spot transactions, forward transactions, options transactions, and swap transactions.

\section{Spot Transaction}

Spot transactions, if understood lexically, have many meanings. However, there are two meanings relevant to this context, namely cash and immediately. If it refers to the lexical meaning, then a spot transaction can be interpreted as a transaction whose delivery is carried out on the day in question or on the following several days. The definition of transaction spot above is following the current transaction phenomenon. In this regard, spot transactions can be carried out in three ways, known as value today, value tomorrow, and value spot [10].

\section{Forward Transaction}

Futures transactions are transactions in the currency of a country with the currency of another country, the delivery of which is carried out at a future time [11]. The meaning of future time is not the same as the time referred to in the spot value and tomorrow's value. In future transactions, the time is longer than that. Usually, the handover in future transactions is carried out between the next one to six months. To better understand it, here will be presented a simple example. For example, two parties transact some currencies. Both have set the exchange rate at the time of the contract (the forward rate is not the same as the spot rate at the time of the contract). However, the delivery is carried out in the next six months without regard to the possibility of fluctuations in one of the currencies transacted. In this way, the risk of loss due to currency fluctuations can be minimized. Benefits like this are felt by a company that wants to export or import with future payments. However, in this transaction, there is also the possibility to make big speculations, especially since one of the parties concerned can influence the value of a currency. An example of a rupiah currency transaction with the US dollar. At the time of the contract, it was agreed that the exchange rate was US\$ 1 to Rp 14,000 (different from the spot rate at the time of the contract). Apparently, in the next six months, the rupiah exchange rate fluctuated against the US dollar, reaching US\$ 1 to Rp. 14,500. In an event like this, the rupiah holder will benefit as much as the difference between the exchange rate at the time of contracting and the spot rate in the next six months (during delivery). Or, it could be the other way around, namely the appreciation of the rupiah currency. Of course, the parties who control the dollar will get a profit or profit as much as the difference in the exchange rate is concerned. 


\section{Option Transaction}

An option transaction is a transaction based on a contract agreement to give the buyer the right without obligation to buy or sell a nominal amount of a foreign currency at a certain price (strike price) and a certain time in the future during the period of the contract agreement. The type of forex option transaction is one of the banking derivative transactions because the forex option uses a certain foreign exchange rate value as the principal reference for the transaction. In practice there are two types of options contracts, namely, call options and put options.

a. A call option is the right to buy a foreign currency;

b. A put option is the right to sell a certain currency in the option contract.

\section{Swap Transaction}

A barter transaction or Swap Transaction is a transaction of some currencies between different countries in which both parties combine the two currencies in question in cash, followed by buying and then reselling the same currency in cash and arrears, so that the arrears are made in cash together with different time limits [12]. Transactions like this are mostly carried out by banks if the bank experiences an excess of a currency type. For example, bank A has an excess of currency deposited by customers in the form of US\$ foreign currency deposits, while the majority of loans are in rupiah. To make a balance, barter transactions can be carried out. Or, transactions like this can be made by individuals to banks. Transactions like this, on the one hand, are the same as the pawn system, but on the other hand, they are different. The difference in question lies in the obligation of one of the parties to pay a premium at the time of the future transaction.

\subsubsection{Sharia Law on Foreign Exchange Transactions (Al-Sharf)}

\section{Legal Basis of Foreign Exchange Transactions (Al-Sharf)}

Basically, the contract used in foreign exchange transactions is buying and selling with foreign currency objects. Buying and selling is a contract that is allowed based on the Qur'an, sunnah, and ijma "ulama". The Qur'an (Word of Allah SWT) which was revealed to the Prophet Muhammad SAW is the eternal legal basis, states the basic and kulliyah rules, has the durability of all time, and can be applied in every atmosphere and community environment. It is universal and comprehensive as the highest source of law.

a. Al-Quran

The Qur'an has provided basic standards regarding the issue of buying and selling or commerce, while the details are laid out in the hadith. The legal basis for buying and selling is regulated in the Qur'an, among others, is found in Surah Al-Baqarah verse 275 :

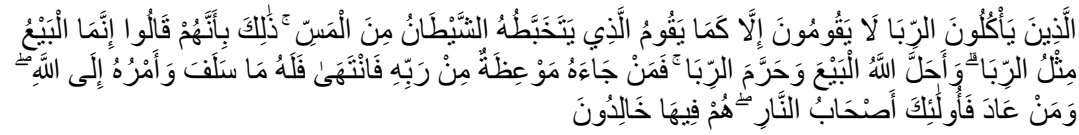

"A person who eats usury cannot stand but like a person who is possessed by a demon because of madness. Their condition is like that because they say that buying and selling are actually the same as usury, even though Allah has permitted buying and selling and forbids usury. Those who have reached him a prohibition from his Lord, then continue to stop taking usury, then for him what he had taken before the prohibition came, and his 
affairs reach Allah. People who return to take usury, then that person is a resident of hell, they will abide in it forever." [13].

The verse rejects the arguments of the polytheists who oppose the prohibition of buying and selling in the Qur'an. The polytheists do not recognize the concept of buying and selling that has been prescribed by Allah SWT in the Qur'an. They consider it identical and the same as the usury system [14].

b. Al-Hadith

The legal basis of buying and selling in the Sunnah of the Prophet Muhammad. Among them is a hadith from Ria'ah ibn Rafi which means: From Rifa'ah ibn Rafi' ra. that the Messenger of Allah. Asked by a friend about what job (profession) is the best? The Prophet at that time replied: the effort of human hands alone and every transaction that is blessed. (HR. Al-Bazzar and al-Hakim) [15].

This hadith encourages us to look for a lawful job because the companions do not ask which job has the most income. But they asked which job was the most blessed. So from here, we can learn that the purpose of seeking sustenance is to seek the most blessing, not just because it makes a lot of money.

\section{Sharia Restrictions That Must Be Implemented in Foreign Exchange Trading}

In muamalah fiqh literature, many prohibitions must be avoided in transactions, including: riba, maisir, gharar, tadlis, ba'i najasy, ihtikar, iktinaz, talaqqi rukban, etc. Among these prohibitions, there are 3 (three) prohibitions that most often occur in banking transactions, namely riba, maysir and gharar. The following is a brief description of the three prohibitions:

a. Riba

Etymologically, riba or usury means ziyadah (additional), to grow, to enlarge. Terminologically, usury is taking additional from principal or capital that is not good or contrary to sharia principles. The usury that was practiced during the jahiliyah period can be divided into two, namely usury on accounts payable and usury of buying and selling. The first group is further divided into usury qardh and usury jahiliyah. The usury of buying and selling is divided into usury fadhl and usury nasi'ah [16].

b. Maysir

Maysir can be interpreted as something that contains elements of gambling (gambling) which places one party at the expense of the other. Every game or match, whether in the form of a game of chance, a game of skill, or a natural event, must avoid the occurrence of a zero-sum game, which is a condition where one or more players have to bear the burden of other players [17].

c. Gharar

Gharar can be interpreted as uncertainty/vagueness or speculation for both parties who transact (uncertainty to both parties) where incomplete information is provided[18]. Gharar can occur in 4 (four) things, namely quantity, quality, price, and delivery time. At the beginning of the transaction, both parties were equally willing, even though the situation was still unclear to both of them. When there is uncertainty in the future, one of the parties will feel wronged.

As the argument and explanation above, so that foreign exchange transaction activities may be carried out, it must be following sharia norms, among others, must be free from elements of riba, maysir, gharar [18]. 


\section{Result and Discussions}

\subsection{Fatwa DSN-MUI .28/DSN-MUI/III/2002 about the Sale and Purchase of Currency (Al- Sharf) [19].}

The background for the issuance of the fatwa began with a request from the Sharia Business Unit of Bank BNI through letter Number: UUS/2/878 requesting an opinion from MUI regarding foreign exchange transactions as well as considering some activities to fulfill various needs that often require currency trading transactions (al-sharf), both between the same currency and between currencies of different types, as well as in the trading tradition of currency transactions, there are several forms of transactions whose legal status according to the view of Islamic teachings differs from one form to another, until it was decided in the Plenary Meeting of the MUI DSN on March 28, 2002.

As for the arguments that are used as references and the basis for the MUI DSN to issue the Fatwa DSN .28/DSN-MUI/III/2002, namely:

a. QS. Al-Baqarah verse 275, Allah says:

"... And Allah has permitted buying and selling and forbidden usury ...."

b. Hadith narrated by al-Baihaqi and Ibn Majah from Abu Sa'id al-Khudri. Rasulullah SAW said:

"Indeed, buying and selling can only be done on the basis of willingness (between the two parties)."

c. Hadith narrated by Muslim, Abu Daud, Tirmizi, Nasa'i, and Ibn Majah, with Muslim text from 'Ubadah bin Shamit. Prophet s.a.w. said:

"(Sell) gold for gold, silver for silver, wheat for wheat, poetry for poetry, dates for dates, and salt for salt (provided it must be) the same and the same and in cash. If the type is different, sell it as you wish if it is done in cash."

d. Ijma' which agrees that the al-sharf contract is determined with certain conditions.

The substance of the Fatwa DSN 28/DSN-MUI/III/2002, the first is to emphasize that currency buying and selling transactions are allowed in principle with the following conditions:

a. First, not for speculation (chance).

b. Secondly, there is a need for transactions or just in case (savings).

c. Third, if the transaction is made against a similar currency, the value must be the same and in cash (attaqabudh).

d. And last, if different types, it must be done with the exchange rate (exchange rate) prevailing at the time the transaction is made and in cash.

\subsection{Analysis of Foreign Exchange Transactions (Al-Sharf) Variety in Review of Islamic Law In Indonesia}

Based on the foregoing description, it can be concluded that buying and selling foreign exchange is allowed, if the buying and selling are intended for the needs of real sector transactions (goods and services), for example, to pay for imported goods to foreign exporters or to travel and shop in Indonesia. Overseas [20].

Based on the Fatwa DSN 28/DSN-MUI/III/2002 about the Sale and Purchase of Currency (Al-Sharf), of the 4 (four) types of existing foreign exchange transactions, 3 (three) of them fall into the haram category, namely forward transactions, swaps, and transactions. option, while the other one is still allowed, namely spot transactions. This is because the transaction model is still considered cash, while two days is considered an unavoidable settlement process and is an 
international transaction. It is different from other types of buying and selling foreign exchange which is considered haram. The considerations for the transaction are prohibited, with the following considerations: firstly because in a forward transaction the price used is the agreed price (muwa'adah) and the delivery is carried out at a later date, even though the price at the time of delivery is not necessarily the same as the agreed value unless it is done in the form of a forward agreement. for purposes not much avoided (lil hajah). Second, swap and options transactions contain more elements of maisir (speculation) which are prohibited in Islam [21].

\section{a. Forward Transactions Contain Riba Elements}

Forward transactions (future transactions) are usually carried out to avoid the risk of exchange rate fluctuations, especially in the future [22]. For example, an Indonesian entrepreneur needs a certain amount of dollars to pay for imported goods in the next three months (according to the time of the contract with the importing party), while he cannot predict how much the spot rate will be for the next three months. To avoid fluctuations in the exchange rate, he made forward transactions for the next three months. The trick is that the transaction is carried out today, but the delivery is carried out in the next three months. The exchange rate in this transaction is not the same as the current spot rate but is higher.

\section{b. Swap Transactions Contain an Element of Speculation}

A simple barter transaction (swap transaction) is described as follows: An entrepreneur has a certain amount of dollars, while he needs rupiah. One year down the line, he needed those dollars back. Therefore, he exchanged dollars for rupiah to a bank by the spot rate at that time, with the condition that one year ahead (on the date specified) the dollar must be returned by the bank at the same exchange rate as the spot rate at the time of the transaction. . The bank agrees to the terms provided that the entrepreneur must pay a premium in a certain percentage of the rupiah he receives, for example, $8 \%$ of the amount of rupiah he receives. To get the same amount of dollars in the next year, the entrepreneur must provide as much rupiah as previously received, plus the specified percentage. If observed from the legal dimension, this transaction includes buying and selling al-ajl in addition to containing usury. Regarding the Sharf terms above, this swap transaction cannot be justified. Thus, this transaction contains legal weaknesses, namely, it contains elements of usury and violates one of the sharf requirements, namely al-ajil.

\section{c. Options Transactions Contain an Element of Speculation}

As previously explained, an option transaction is a contract to obtain the right to buy or the right to sell which does not have to be carried out against foreign currencies at a price and time at a certain end date, so that the law is unlawful because like swap transactions, options transactions contain elements maisir (speculation).

\section{d. Spot Transactions Are Allowed In Islam}

Applicatively, spot transactions can be described as follows. Someone who needs a certain amount of dollars to pay for goods imported from America. To fulfill this need, a person must buy dollars in the foreign exchange market the required amount at the current spot rate (the buyer, on the one hand, the foreign exchange market on the other). In this spot 
transaction, the handover of the currency being traded takes place at the time of the transaction, or at least the next day or two [23].

\section{Conclusion}

The Fatwa DSN 28/DSN-MUI/III/2002 gives the opinion that basically, currency trading (al-Sharf) in accordance with the provisions of Islamic law is currency trading which is carried out in cash and the value is the same. meaning that each party must receive or deliver the currency at the same time. If the currencies are different, then the transaction must be made at the same exchange rate at the time of the transaction and must be made in cash. The transaction will be invalid if a foreign currency sale and purchase transaction whose value is set at present will be enforced in the future. This transaction must still be guided by the study of fiqh muamalah, to avoid elements that are prohibited by sharia, namely speculation, maisir, and usury.

The Fatwa DSN 28/DSN-MUI/III/2002 emphasizes that not all types of foreign exchange transactions can be justified under Islamic law. The only thing that is acceptable in the practice of Islamic muamalah is a spot type of foreign exchange transaction because the transaction model is still considered cash, while two days is considered an unavoidable settlement process and is an international transaction. Meanwhile, the other three types of forwards, swaps, and options are not allowed because they contain elements of prohibition, with the following considerations: firstly because in a forward transaction the price used is the agreed price (muwa'adah) and the delivery is carried out at a later date, even though the price at the time of delivery is not necessarily the same as the agreed value unless it is done in the form of a forward agreement. for purposes not much avoided (lil hajah). Second, swap and options transactions contain more elements of maisir (speculation) which are prohibited in Islam.

\section{References}

[1] Indonesia-Investments Writer Team: Ekonomi Indonesia: Inflasi, Suku Bunga, Perdangangan \& Update Rupiah, https://www.indonesia-investments.com/id/berita/kolom-berita/ekonomi-indonesiainflasi-perdagangan-suku-bunga-update-rupiah/item5358. Indonesia-investments.com, Jakarta (2015) [2]Kompas.com Writer: Kenapa Nilai Kurs Valuta Asing Naik?, https://money.kompas.com/read/2015/07/12/224505026/Kenapa.Nilai.Kurs.Valuta.Asing.Naik.?pag =all. Kompas.com, Jakarta (2015)

[3] Novita Intan \& Friska Yolanda: Dampak Corona, BI Turunkan GWM Valuta Asing dan Rupiah, (Jakarta: Republika.co.id, 2020) https://republika.co.id/berita/q6k5ib370/dampak-corona-bi-turunkangwm-valutas-asing-dan-rupiah, Republika.co.id, Jakarta (2020)

[4] Setiawan Budi Utomo, et al.: Analisis Kesesuaian Instrumen Hedge Konvensional Terhadap Prinsip Syariah. Jurnal Media Riset dan Manajemen FE Trisakti, Jakarta (2008)

[5] Muhammad Sulhan: Transaksi Valuta Asing (Al-Sharf) Dalam Prespektif Islam. Jurnal Iqtishoduna Vol.4 Number 2, Malang (2008)

[6] Nanik Indrawati: Aplikasi Manajemen Risiko pada Investasi Foreign Exchange (FOREX) (Studi Pada PT. Victory International Futures Kantor Cabang Malang). Thesis Published. UIN Maulana Malik Ibrahim, Malang (2009).

[7] Rita Sahara: Transaksi Valuta Asing dalam Prespektif Ekonomi Islam. Thesis Published. UIN Raden Fatah, Palembang (2010)

[8] Soerjono Soekanto: Pengantar Penelitian Hukum. pp. 42, UI Press, Jakarta (2010) 
[9] Hady Hamdy: Ekonomi Internasional Teori dan Kebijakan Keuangan Internasional. Ghalia Indonesia, Jakarta (2001)

[10] Dahlan Siamat: Manajemen Lembaga Keuangan. Pp.181-182. FE Universitas Indonesia, Jakarta (2009)

[11] Ahmad Jamali: Dasar-Dasar Keuangan Internasional, Pp. 46, BPEF, Yogyakarta (1998)

[12] Ahmad Jamali: Dasar-Dasar Keuangan Internasional, Pp. 4 BPEF, Yogyakarta (1998)

[13] Departemen Agama RI Writer Team: Al-Qur'an and Translation, Pp.47. PT. SygmaExamedia Arkanleema, Bandung (2007)

[14] Dimyauddin Djuwain:. Pengantar Fiqh Muamalah, Pp.71 Pustaka Belajar, Yogyakarta (2008)

[15] Al-hafizh Ibnu Hajar Al-Asqalani: Bulughul Maram (Translate by A. Hassan). Pustaka Nuun, Semarang (2011)

[16] Sayyid Sabiq: Fiqh Sunnah (Translate by H. Kamaluddin A) Pp.23. Pena Pundi Aksara, Jakarta (2006)

[17] Azmatkhan Shohibul Faroji: The Return of Dinar Dirham, Pp.28. Khalifa Femark Nusantara, Jakarta (2014)

[18] Agustianto: Perdagangan Valas Dalam Prespektif Ekonomi Islam. https://agustianto.com/?p=396, Agustianto.com, Jakarta (2011)

[19] Dewan Syariah Nasional-Majelis Ulama Indonesia: Fatwa DSN-MUI Number 28/DSNMUI/III/2002 about Jual Beli Mata Uang (Al-Sharf)

[20] Muslich Ahmad Wardi: Fiqh Muamalat. Amzah, Jakarta (2013)

[21] Moh. Mufid: Kaidah Fikih Ekonomi dan Keuangan Kontemporer. Pp.169. Prenada Media, Jakarta (2019)

[22] Lastuti Abubakar \& Tri Handayani: Transaksi Lindung Nilai (Hedging) Dalam Praktik [22] Perbankan Dan Implikasinya Terhadap Pembaruan Hukum Kontrak Nasional. Rechtidee,Vol.11.Number 1, Bangkalan (2016)

[23] Asmir: Bank dan Lembaga Keuangan Lainnya. Raja Grafindo Persada, Jakarta (2013) 